\title{
Production of Fuels From HDPE and LDPE Plastic Waste via Pyrolysis Methods
}

\author{
Enggar Hero Istoto $^{1 .}$, Widayat $^{2}$, and Singgih Saptadi ${ }^{3}$ \\ ${ }^{1}$ Master Program of Energy, School of Postgraduate Studies, Diponegoro University, Semarang - Indonesia \\ ${ }^{2}$ Department of Chemical Engineering, Faculty of Engineering, Diponegoro University, Semarang - Indonesia \\ ${ }^{3}$ Department of Industrial Engineering, Faculty of Engineering, Diponegoro University, Semarang - Indonesia
}

\begin{abstract}
This study to calculate and composition of fuels from polyethylene waste production per litre. Production method with pyrolysis at $450-621^{\circ} \mathrm{C}$ without catalyst, and quantitative method with GC-MS. The results product of $5 \mathrm{~kg}$ pyrolysis HDPE are 3.25 litres of naphtha; 0.85 litre of gasoline; 0.325 litre of diesel fuel; and 18.06 grams of residues. Then The product of $5 \mathrm{~kg}$ pyrolysis LDPE are 0.5 litres of naphtha; 2.9 litre of gasoline; 0.1 litre of diesel fuel; and 19 grams of residues. The conclusions in this study were product of $5 \mathrm{~kg}$ pyrolysis HDPE are 3.25 litres of naphtha; 0.85 litre of gasoline; 0.325 litre of diesel fuel; and 18.06 grams of residues. Then The product of $5 \mathrm{~kg}$ pyrolysis LDPE are 2.9 litre of gasoline, 0.1 litre of diesel fuel, and 19 grams of residues. Composition of fuels from polyethylene (HDPE and LDPE) pyrolysis are naphtha, gasoline, and residues.
\end{abstract}

Keywords: Fuels; HDPE; LDPE; GC-MS; Pyrolysis.

\section{Introduction}

The topic of production fuels from plastic waste has been widely analyzed by many researchers. A number of studies have examined the production fules from HDPE and LDPE waste. Indonesia is one of the great producer number 2 plastic waste in the world 3,22 million metrics tonne per year and 0,48-1,29 million metrics tonne per year of plastic waste in ocean [1]. So, productions energy from plastic waste is one of methods to managed plastic waste in the world especially in Indonesia.

Biofuel industry was employed 1,724 million labours in the world, especially in Indonesia have been 154.300 labours worked at biofuel industry from palm oil [2]. This is indicated to develop biofuel industry from plastic waste was prospective too.

The relationship between production of fuels from HDPE and LDPE plastic waste via pyrolysis methods has been an active research area will explain at Theory and Methodology.

This study discusses to calculate and composition of fuels from polyethylene waste production per litre. The process used pyrolysis methods at $450-621^{\circ} \mathrm{C}$ without catalyst until 3 hours for LDPE and 4 hours for HDPE. The products was analyzed with kuantitative and qualitative analysis. Qualitative analysis this products with GC-MS method.

The results of this study can be used as the foundation of policy making especially in the energy and environment field, and development of industrial fuels (biofuel and biodiesel) from plastics waste in Indonesia.

\section{Theory}

Pyrolysis was the process of degradation of a material with high temperature without oxygen (thermochemical process), in degrading plastic material it takes a temperature between $300-500^{\circ} \mathrm{C}$ to become gas then condensed, then distillated to produced oil and the pulp in the form of char [3].

Several studies related to the production of biodiesel from plastic HDPE and LDPE have been carried out by both domestic and foreign researchers. Pyrolysis plastic oil increased efficiency by $15-20 \%$ in 100 cc bajaj motors compared to using gasoline, increased thermal efficiency gasoline engine, pyrolysis oil from HDPE has the same density as gasoline and pyrolysis oil from LDPE has the same density as diesel fuel, and pyrolysis process at a fairly low temperature required a catalyst to be efficient in combustion [4].

Pyrolysis oil from LDPE has a content similar to diesel fuel, although in viscosity and the calorific value wass still a little low; the advantage of pyrolysis oil has lower carbon residue and sulfur so it was more environmentally friendly; in economic, for each pyrolysis oil production from LDPE waste ranging from 14-18 rupees it is much cheaper than the price of diesel fuel which reaches 40 rupees per litre [5].

Processing of LDPE plastic waste with microwave pyrolysis method, from this method showed that microwave pyrolysis method produced plastic biodiesel

\footnotetext{
* Corresponding author: enggarheroistoto@student.undip.ac.id
} 
for 60 minutes to obtain $23.65 \%$ liquid, $30.41 \% \mathrm{CH}_{4}$ gas, and solid $4.67 \%$ at $500^{\circ} \mathrm{C}$ [6].

The best efficiency decomposition results in decomposing plastic waste occur at $420^{\circ} \mathrm{C}$ with a operating time of 60 minutes, and pyrolysis oil from plastic waste (HDPE and LDPE) has characteristics were not much different from the characteristics of diesel oil [7].

Production of biodiesel from plastic HDPE using the pyrolysis method heated $330-490^{\circ} \mathrm{C}$ resulted quality of fuel oil (biodiesel) better than diesel oil [8].

\section{Methodology}

Based on previous research data, this study was conducted using the pyrolysis method with a temperature of $450-621^{\circ} \mathrm{C}$ without using a catalyst, and quantitative analysis. Quantitative analysis used the GC-MS method.

\section{Research Model}

\subsection{Research Materia}

HDPE and LDPE plastics that have been chopped and obtained from plastic collectors in Semarang City. Fuel using $5.5 \mathrm{~kg}$ LPG from PT. Pertamina (Persero).

\subsection{Pyrolsis Process}

Cleaned and chopped HDPE and LDPE plastic samples of $5 \mathrm{~kg}$ each were put into the reactor. The plastic is heated using the pyrolysis method with a temperature of $450-621{ }^{\circ} \mathrm{C}$ without catalyst for 4 hours for HDPE and 3 hours for LDPE. The gas produced from the reactor were condensed into a liquid phase using a condenser. The product conversion calculation produced is used as follows:

Liquid Products $(\%)=($ Litre of product $/$ Litre of product total) $x$ $100 \%$

Solid products or Residues $(\mathrm{Kg} / \mathrm{Kg} \%)=(\mathrm{Kg}$ of product $/$ Mass of raw material) $\times 100 \%$

Gas Products $=100 \%$ - Liquid Products (\%)

Products from plastic pyrolysis in the form of naphtha, gasoline, and diesel fuel and produced residues were analyzed by GC-MS at the Diponegoro University Integrated Laboratory.

\section{Result}

\subsection{Pyrolysis of HDPE Plastics Waste}

HDPE plastic pyrolysis carried out for 4 hours using 5.5 $\mathrm{kg}$ LPG without catalyst. The process produced $3.25 \mathrm{~L}$ in the form of naphtha; oil fraction 1 (F1) as much as $1 \mathrm{~L}$; oil fraction 2 (F2) as much as $0.25 \mathrm{~L}$; and residues as much as 18.06 grams. Processing $1 \mathrm{~kg}$ of plastic waste equal to 1 litre of fuel[9]. If the results are included in the formula it will be produced as follows: Naphtha : $(3.25$ $\mathrm{L} / 5 \mathrm{~L}) \times 100 \%=65 \%$
F1 : $(0.325 \mathrm{~L} / 5 \mathrm{~L}) \times 100 \%=6,5 \%$

F2 : $(0.85 \mathrm{~L} / 5 \mathrm{~L}) \times 100 \%=17 \%$

Residues : $(0.01806 \mathrm{Kg} / 5 \mathrm{Kg}) \times 100 \%=0.3612 \% \approx 0,36 \%$ Gas : $100 \%-(65 \%+6.5 \%+17 \%)=11.5 \%$. Overall the products produced during the pyrolysis process of HDPE plastics are $88.86 \%$ non-gas and $11.5 \%$ gas.

\subsection{Pyrolysis of LDPE Plastics Waste}

LDPE plastic pyrolysis carried out for 3 hours using 5.5 $\mathrm{kg}$ LPG without catalyst. The process produced oil fraction $1(\mathrm{~F} 1)$ as much as $0.1 \mathrm{~L}$; oil fraction $2(\mathrm{~F} 2)$ as much as $2.9 \mathrm{~L}$; and residues as much as 19 grams. Processing $1 \mathrm{~kg}$ of plastic waste equal to 1 litre of fuel[9]. If the results are included in the formula it will be produced as follows:

F1 : $(0,1 \mathrm{~L} / 5 \mathrm{~L}) \times 100 \%=2 \%$ $\mathrm{F} 2:(2,9 \mathrm{~L} / 5 \mathrm{~L}) \times 100 \%=58 \%$ Residues : $(0,019 \mathrm{Kg} / 5 \mathrm{Kg}) \times 100 \%=0.38 \%$ Gas : $100 \%-(2 \%+58 \%)=40 \%$.

Overall the products produced during the pyrolysis process of LDPE plastics are $60 \%$ non-gas and $40 \%$ gas.

Table 1. Pyrolysis of HDPE and LDPE Plastics Waste

\begin{tabular}{|cccc|}
\hline & LDPE & HDPE & Unit \\
\hline Naphtha & 0 & 65 & $\%$ \\
\hline Diesel Oil (F1) & 2 & 6.5 & $\%$ \\
\hline Gasoline (F2) & 58 & 17 & $\%$ \\
\hline Residues & 0.38 & 0.36 & $\%$ \\
\hline Gas & 40 & 11.5 & $\%$ \\
\hline
\end{tabular}

\subsection{GC-MS of HDPE Plastics Waste}

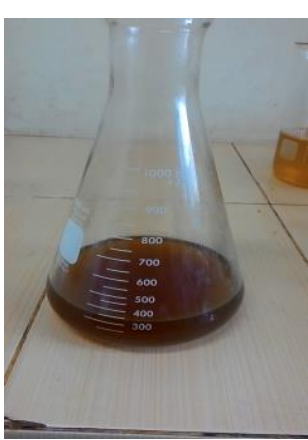

(a)

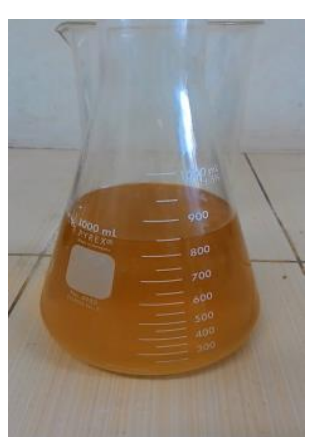

(b)
Fig. 1. Pyrolysis oil of HDPE plastics waste (a) Fraction 1 and (b) Fraction 2

In Figure 1a, pyrolysis oil of HDPE plastics waste saw dark brown. Most likely the oil content in it includes the $\mathrm{C}$ chain which was quite long to very long. Physically similar to diesel oil, kerosene, and heavy oil. In Figure $1 \mathrm{~b}$, pyrolysis oil of HDPE plastics waste saw yellowishbrown. It is likely that the oil content in it includes the $\mathrm{C}$ chain, which was quite short to quite long. Physically 
similar to gasoline, kerosene, and there is the possibility of a little diesel oil.

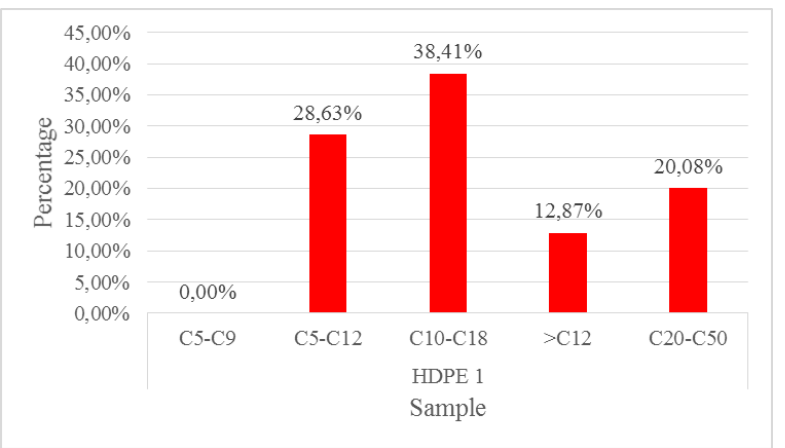

(a)

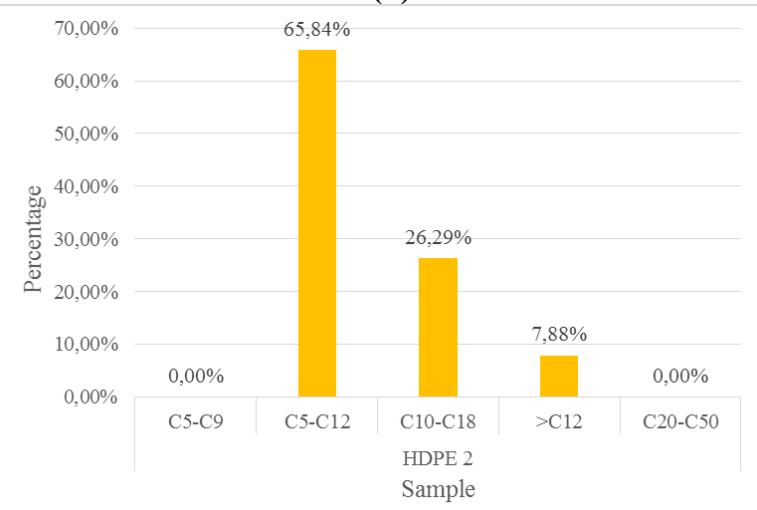

(b)

Fig. 2. GC-MS results from pyrolysis of HDPE plastic waste (a) Fraction 1 and (b) Fraction 2

In figure $2 \mathrm{a}$, the content of the fraction 1 from the pyrolysis of HDPE plastic waste was proven to be dominated by kerosene (C10-C18) as much as $38.41 \%$, gasoline (C5-C12) as much as $28.63 \%$, heavy oil (C20$\mathrm{C} 50$ ) as much $20.08 \%$, and diesel oil (> C12) as much as $12.87 \%$. In Figure 2b, the content of the fraction 2 from the pyrolysis of HDPE plastic waste was proven to be dominated by gasoline (C5-C12) as much as $65,84 \%$, kerosene (C10-C18) as much as $26.29 \%$, and diesel oil ( $>\mathrm{C} 12$ ) as much $7.88 \%$. The $\mathrm{C} 5-\mathrm{C} 12$ chain is classified as gasoline, $\mathrm{C} 10-\mathrm{C} 18$ is classified as kerosene, $>\mathrm{C} 12$ is classified as diesel oil, and C20-C50 is classified as oil oil [10].

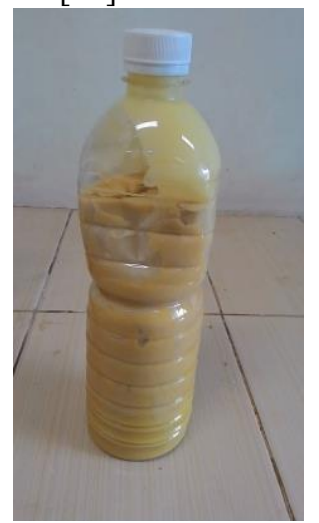

(a)

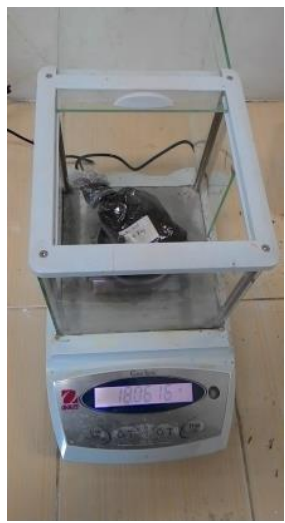

(b)
Fig. 3. Solid phase from pyrolysis oil of HDPE plastics waste (a) Like Naphtha and (b) Residues
In Figure 3a, it appears that the results were solids resulting from the pyrolysis of HDPE plastic waste in the form of a type of naphtha and colored slightly brown. Most likely other than naphtha there is another ingredient in the naphtha. In Figure $3 b$, the results of pyrolysis of HDPE plastic waste also produced black residues. The activated carbon produced in the pyrolysis is 18.06 grams.

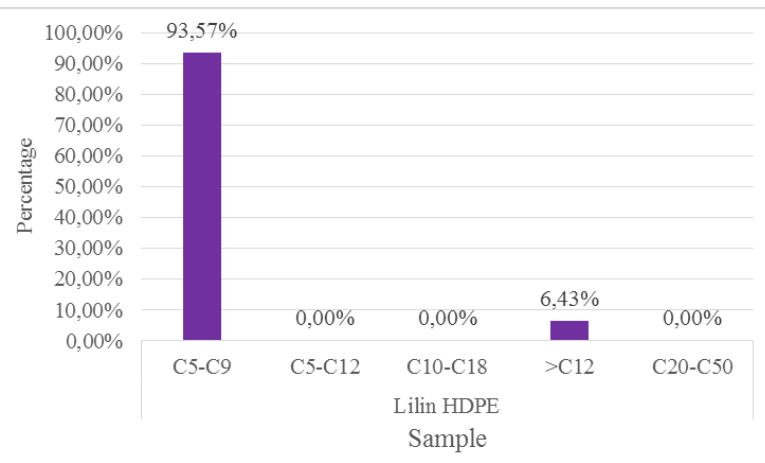

Fig. 4. The result of GC-MS is a type of naphtha (Figure 3a) resulting from the pyrolysis of HDPE plastics waste

In figure 4 , the content of a type of naphtha from the pyrolysis of HDPE plastics waste was proven to be dominated by naphtha (C5-C9) as much as $93.57 \%$, and diesel oil $(>\mathrm{C} 12)$ as much as $6.43 \%$. This is in accordance with the physical appearance observed by the researcher.

\subsection{GC-MS of LDPE Plastics Waste}

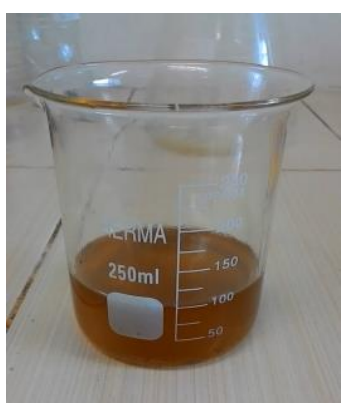

(a)

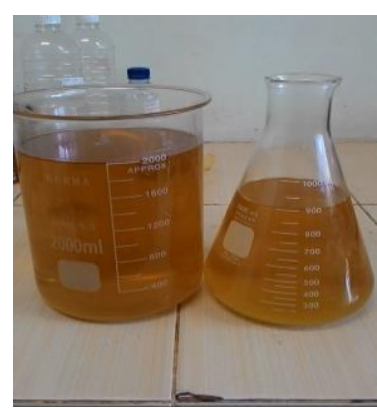

(b)
Fig. 5. Pyrolysis oil of LDPE plastics waste (a) Fraction 1 and (b) Fraction 2

In Figure 5a, the pyrolysis oil of LDPE plastic waste was dark brown. Most likely the oil content in it includes the $\mathrm{C}$ chain which is quite long to very long. Physically similar to kerosene, diesel oil, kerosene and heavy oil. In Figure $5 b$, the pyrolysis oil of LDPE plastic waste is dark brown. Most likely the oil content in it includes the $\mathrm{C}$ chain which was quite short to quite long. Physically similar to kerosene, diesel oil and the possibility of gasoline, or a little heavy oil. 


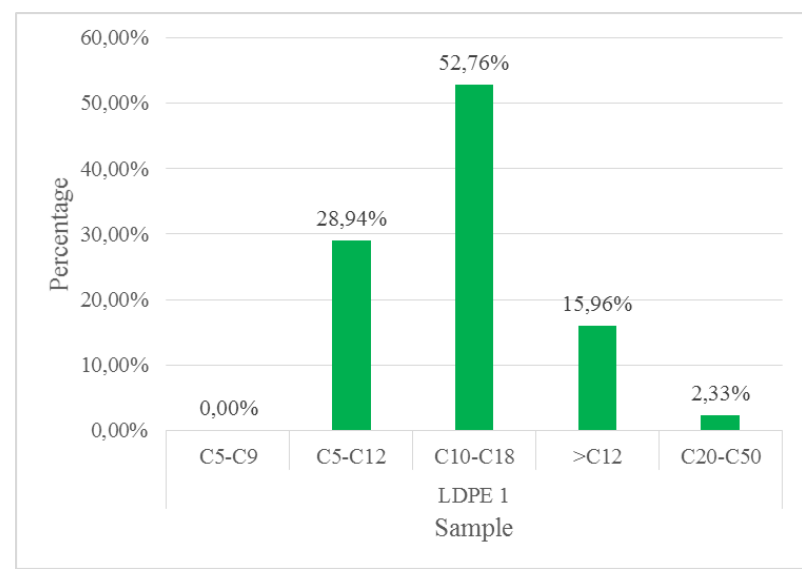

(a)

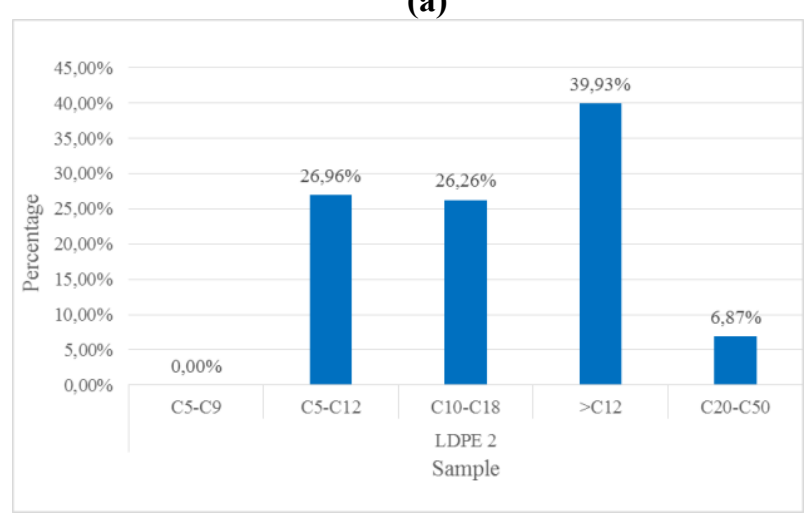

(b)

Fig. 6. GC-MS results from pyrolysis of LDPE plastic waste (a) Fraction 1 and (b) Fraction 2

In figure $6 \mathrm{a}$, the content of the 1 st fraction from the pyrolysis of LDPE plastic waste was proven to be dominated by kerosene (C10-C18) as much as $52.76 \%$, gasoline (C5-C12) as much as 28,94\%, diesel oil (> C12) as much as $15.96 \%$, and heavy oil (C20-C50) as much as $2.33 \%$. In figure $6 \mathrm{~b}$, the content of the fraction 2 from the pyrolysis of LDPE plastics waste was proven to be dominated by diesel oil (> C12) as much as $39.93 \%$, gasoline (C5-C12) as much as 26,96\%, kerosene (C10$\mathrm{C} 18$ ) as much as $26.26 \%$, and heavy oil (C20-C50) as much as $6.87 \%$. The $\mathrm{C} 5-\mathrm{C} 12$ chain is classified as gasoline, $\mathrm{C} 10-\mathrm{C} 18$ is classified as kerosene, $>\mathrm{C} 12$ is classified as diesel oil, and C20-C50 is classified as heavy oil[10].

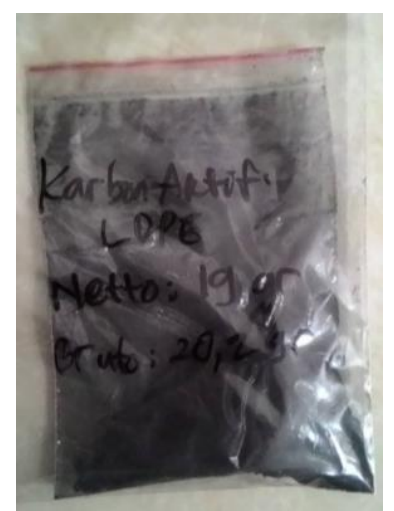

Fig. 7. The results of residues from pyrolysis oil of LDPE plastics waste
In Figure 7, the results of pyrolysis of LDPE plastic waste also produced black residues. The activated carbon produced in the pyrolysis was 19 grams.

\section{Conclusion}

The product of $5 \mathrm{~kg}$ pyrolysis HDPE are 3.25 litres of naphtha; 0.85 litre of gasoline; 0.325 litre of diesel fuel; and 18.06 grams of residues. Then The product of $5 \mathrm{~kg}$ pyrolysis LDPE are 2.9 litres of gasoline, 0.1 litre of diesel fuel, and 19 grams of residues. Composition of fuels from polyethylene (HDPE and LDPE) pyrolysis were naphtha, gasoline, and residues.

\section{References}

1. Jenna R. Jambeck, Roland Geyer, Chris Wilcox, Theodore R. Siegler, Miriam Perryman, Anthony Andrady, Ramani Narayan, and Kara Lavender Law, Plastic waste inputs from land into the ocean, Science Journal, 347 (6223): 768-770 (2015)

2. [IRENA] International Renewable Energy Agency, Renewable Energy and Jobs Annual Review 2017, Abu Dhabi: IRENA (2017)

3. Neha Patni, Pallav Shah, Shruti Agarwal, and Piyush Singhal, Alternate strategies for conversion of waste plastic to fuels, ISRN Renewable Energy 2013: 1-7 (2013)

4. Raj Kumar Yadav, and Yogesh Kumar Tembhurne, Waste plastic fuel used in petrol engine, International Journal of Mechanical Engineering and Technology (IJMET) 7 (1): 1-4 (2016)

5. Sudhir B. Desai and Chetan K. Galage, Production and Analysis of Pyrolysis oil from waste plastic in Kolhapur city (International Journal of Engineering Research and General Science, 3 (1): 590-595 (2015)

6. S.R. Juliastuti, Nuniek Hendrianie, Arief Febrianto, and Diki Dinar Ramadhika, Pengolahan limbah plastik kemasan multilayer LDPE (Low Density Poly Ethilene) dengan menggunakan metode Pirolisis Microwave, Prosiding Seminar Nasional Teknik Kimia "Kejuangan” Yogyakarta: 1-7 (2015)

7. Aprian Ramadhan P. and Munawar Ali, Pengolahan sampah plastik menjadi minyak menggunakan proses pirolisis, Jurnal Ilmiah Teknik Lingkungan, 4 (1): 44-53 (2013)

8. M.Z.H. Khan, M. Sultana, M. R. Al-Mamun, and M. R. Hasan, Pyrolytic waste plastic oil and its diesel blend: fuel characterization, Journal of Environmental and Public Health, 2016: 1-6 (2016)

9. Cold Climate Innovation, Blest Plastic-to-Fuel Project Report - Results and Recommendations for a Northern Climate, Japan: Yukon Research Centre, Yukon College (2014)

10. Abdullah Al Ashraf and Abdullah Al Aftab, Destillation Process of Crude Oil, Thesis, Doha: Qatar University (2012) 